\title{
Antimicrobial Activity of Aloevera barbedensis, Daucus carota, Emblica officinalis, Honey and Punica granatum and Formulation of a Health Drink and Salad
}

\author{
Jeswin Philip, Sheila John and Priya lyer* \\ Department of Biotechnology, Women`s Christian College, College Road, Chennai-600006, Tamil Nadu, India. \\ E.mail: brajuraj@yahoo.com
}

Received 18 August 2011; Received in revised form 11 March 2012; Accepted 23 March 2012

\begin{abstract}
Aims: Indian folk medicine has been in practice from time immemorial. Traditional medicine interconnects our body with nature for a healthy living. The naturally occurring antimicrobials in food vary in their efficacy and function, toxicology, safety and mechanism of action against microorganisms.

Methodology and Results: The study revitalizes the traditional system of medicine in order to achieve self reliance in health care and health for all by analyzing the antimicrobial property of aqueous extracts of aloevera (Aloevera barbedensis), carrot (Daucus carota), Indian gooseberry (Emblica officinalis), honey and pomegranate (Punica granatum), and to assess the reason for inhibition of growth of pathogenic organisms by DNA and protein analysis. Various aqueous extracts showed inhibition to microrganisms like Escherichia coli, Pseudomonas aeruginosa, Salmonella typhi, Shigella flexineri and Staphylococcus aureus.

Conclusion significance and impact of study: The study also formulated and standardized a nourishing health drink and salad using the tested foods and estimated their shelf life and nutritive value. The health drink and salad had a low protein, low fat and moderate carbohydrate content. Therapeutically this drink and salad can be used to treat obesity.
\end{abstract}

Keywords: Antimicrobial property, aloevera, carrot, amla, honey and pomegranate

\section{INTRODUCTION}

Health is of prime concern in the present scenario. There is a growing concern about chronic health problems with rapidly changing food environment. A lot of advancement has been made in the field of medicine where pharmaceuticals play a vital role in the healing process and the importance of naturally occurring food items with medicinal value is being ignored. The practice of consuming natural foods must be cultivated rather than loading one's body with chemicals. Research is being carried out so that an alternative to antibiotics can be obtained by testing natural products with medicinal properties. Indian folk medicine has been in practice from time immemorial. Traditional medicine interconnects our body with nature for a healthy living. The term "antimicrobial" refers to natural or synthetic substances that kill or inhibit the growth of microorganisms. Plants, as extracts and in various forms are being used for centuries in different traditional system of medicines particularly those caused by pathogenic bacteria, viruses and fungi. Naturally occurring antimicrobials are abundant in the environment. The naturally occurring antimicrobials vary in their efficacy and function, toxicology and safety and mechanism of action against microorganisms. Based on the above information the food substance like Aloevera barbedensis - Aloevera, Daucus carota - Carrot, Emblica officinalis - Amla, Honey - Honey, Punica granatum Pomegranate was selected to study their antimicrobial activity. Since they had unique antimicrobial properties a health drink and salad was formulated to make a nutritious food available for consumption and sensory evaluation was done to make the food more palatable. The objectives of the study are to determine the antimicrobial activity of aloevera, carrot, amla, honey and pomegranate quantitatively by serial dilution method and standard well technique. The objective includes the reason for inhibition of pathogenic organisms and to formulate a health drink and salad using aloevera, carrot, amla, honey and pomegranate. The objective will also include palatability and acceptability of the health drink and salad using sensory evaluation techniques, to estimate the shelf life of the formulated health drink and salad and to assess the nutritive value of the health drink and salad.

\section{MATERIALS AND METHODS}

The study was carried out the with objective of determining the antimicrobial property of aqueous extracts of aloevera, carrot, amla, honey and pomegranate using experimental procedures in three parts.

\section{Extraction}

The raw materials aloevera, carrot, amla, honey and pomegranate were collected. The extract was prepared. (a) The sample was taken (20 gm) and ground in a mortar 
which was surface sterilized by ethanol. (b) The sample was dissolved in $100 \mathrm{ml}$ of water. (c) The extracts were collected and stored in a sterile container. (d) The equipment and glassware were sterilized. (e) Preparation of media namely Muller Hinton Agar. (f) Provision of stock culture. (g) Preparation of agar plates for immediate use.

\section{Testing antimicrobial activity of the experimental extracts}

The first step was to do a sterility check on the nutrient broth and the second step was to perform serial dilution test to check for inhibitory concentration of the extract. Based on the findings of the broth dilution method, standard well technique was performed to obtain zones of inhibition. Muller Hinton agar was prepared and left to cool at $45{ }^{\circ} \mathrm{C}$. The agar was then poured into Petri plates, sterility check was performed, the medium was preseeded with the microorganism using a sterile cotton swab dipped in the inoculum, the well puncture was dipped in ethanol and sterilized by flaming, two wells were made and spaced out at equal intervals, with the help of a micro pipette, $20 \mu \mathrm{L}$ of the extract was pipetted into each well, Antibiogram was performed using antibiotics viz., Amikacin, Ampicillin, Bacitracin, Chloramphenicol, Gentamycin, and Streptomycin, the plates were left in an incubator at $37{ }^{\circ} \mathrm{C}$ for $24 \mathrm{~h}$ and observations were made, Antibiogram was performed using antibiotics to obtain zone of inhibition for comparison with those of extract.

\section{Analyze the reason of inhibition of growth of the organism by the experimental extracts}

(a) Preparation of culture with equal number of cells. (b) Treating of the culture with the experimental extracts. (c) Centrifugation of the culture at $12000 \mathrm{rpm}$ for $10 \mathrm{~min}$ to collect the cells. (d) Resuspension of cells in saline solution. (e) Extraction of DNA by lysis of the cell. (f) Precipitation and extraction of protein. (g) Analysis of the DNA from the supernatant. (h) Analysis of the protein from the precipitate. (i) Reading the colour developed by the spectrometer at $640 \mathrm{~nm}$. (j) Quantification of the tested optical density using standard optical density.

\section{Choice of the test organism}

The antimicrobial activity was tested against food borne pathogens that enter the body through the gut and causes various diseases. The pathogens selected include: Escherichia coli, Pseudomonas aeruginosa, Salmonella typhi, Shigella flexineri and Staphylococcus aureus

\section{Formulation and standardization of a health drink and a salad}

The food substances selected for the health drink and salad include aloevera (juice), carrot, amLa, honey and pomegranate. The food substances selected for standardization were fresh and without any contamination. Twelve post graduate students from the Department of
Home Science, Women's Christian College, Chennai were chosen as panel members to score the health drink and salad. The acceptability and palatability of the health drink and salad was evaluated and the shelf life was determined by standard plate count, serial dilution method and pours plate method at room and refrigerated temperatures. The nutritive value of the health drink and salad was also assessed.

\section{Nutritive analysis of the formulated drink and salad}

In order to estimate the nutrients in the health drink and salad the nutritive value was calculated. The energy was calculated using the ICMR (2002) values. The formulated health drink and salad were analyzed bio-chemically for protein, carbohydrate, fat, vitamin A and vitamin C. $100 \mathrm{ml}$ of the health drink and salad were used for biochemical analysis.

\section{RESULTS AND DISCUSSION}

\section{Qualitative effect of the experimental extracts on the test organism}

The minimum inhibitory concentration obtained by the serial dilution method is presented in Table 1.

Aloevera: Results of serial dilution method reveals that the growth of Staphylococcus aureus was inhibited at high concentration (1/10) of aloevera extract. A moderate concentration of aloevera extract was needed to inhibit the growth of Escherichia coli, Pseudomonas aeruginosa and Salmonella typhi. Since Staphylococcus is becoming resistant to antibiotics, this result is significant.

Carrot: Moderate concentration of carrot was needed to inhibit the growth of Escherichia coli while a higher concentration is needed to inhibit the growth of Staphylococcus aureus.

Honey: High concentration of honey was needed to inhibit the growth of Escherichia coli, Pseudomonas aeruginosa and Staphylococcus aureus and a moderate concentration was needed to inhibit the growth of Salmonella typhi.

Pomegranate: Higher concentration of pomegranate was needed to inhibit the growth of Staphylococcus aureus and Salmonella typhi while a moderate concentration was needed to inhibit the growth of Escherichia coli.

Amla: High concentration of amla was needed to inhibit the growth of Salmonella typhi and a low concentration of amla is needed to inhibit the growth of Shigella flexineri.

\section{Quantitative effect of the experimental extracts on the test organism}

The results are observed after incubating the plates at 37 ${ }^{\circ} \mathrm{C}$ for $24 \mathrm{~h}$. Result of Table 2 shows that zone of 
Table 1: Results of diluted aqueous extracts

\begin{tabular}{|c|c|c|c|c|c|c|}
\hline \multirow[t]{2}{*}{ S.No. } & \multirow{2}{*}{ ORGANISMS } & \multicolumn{5}{|c|}{ Dilution of extracts } \\
\hline & & $1 / 10$ & $1 / 100$ & $1 / 1000$ & $1 / 10000$ & $1 / 10000$ \\
\hline \multicolumn{7}{|c|}{ Aloevera extract } \\
\hline 1 & Escherichia coli & + & + & - & - & - \\
\hline 2 & Pseudomonas aeruginosa & + & + & - & - & - \\
\hline 3 & Salmonella typhi & + & + & + & + & + \\
\hline 4 & Shigella flexineri & + & + & - & - & - \\
\hline 5 & Staphylococcus aureus & - & - & - & - & - \\
\hline \multicolumn{7}{|l|}{ Carrot } \\
\hline 1 & Escherichia coli & + & + & - & - & - \\
\hline 2 & Pseudomonas aeruginosa & + & + & + & + & + \\
\hline 3 & Salmonella typhi & + & + & + & + & + \\
\hline 4 & Shigella flexineri & + & + & + & + & + \\
\hline 5 & Staphylococcus aureus & + & + & + & - & - \\
\hline \multicolumn{7}{|c|}{ Amla extract } \\
\hline 1 & Escherichia coli & + & + & + & + & + \\
\hline 2 & Pseudomonas aeruginosa & + & + & + & + & + \\
\hline 3 & Salmonella typhi & + & - & - & - & - \\
\hline 4 & Shigella flexineri & + & + & + & - & - \\
\hline 5 & Staphylococcus aureus & + & + & + & + & + \\
\hline
\end{tabular}

\begin{tabular}{|c|c|c|c|c|c|c|}
\hline \multicolumn{7}{|c|}{ Honey } \\
\hline 1 & Escherichia coli & + & - & - & - & - \\
\hline 2 & Pseudomonas aeruginosa & - & - & - & - & - \\
\hline 3 & Salmonella typhi & + & + & + & + & + \\
\hline 4 & Shigella flexineri & + & + & - & - & - \\
\hline 5 & Staphylococcus aureus & - & - & - & - & - \\
\hline
\end{tabular}

\begin{tabular}{ccccccc}
\hline Pomegranate & & & & & \\
\hline 1 & Escherichia coli & + & + & - & - & + \\
2 & Pseudomonas aeruginosa & + & + & + & - & + \\
3 & Salmonella typhi & + & - & + & - & + \\
4 & Shigella flexineri & + & + & - & - & - \\
5 & Staphylococcus aureus & + & - & - & - &
\end{tabular}

-: growth +: no growth

inhibition by standard well technique.

Aloevera extract had good inhibitory effect on E. coli (10 $\mathrm{mm})$, Pseudomonas aeruginosa $(11 \mathrm{~mm})$, Aggary et al., (2005) showed that this leafy plant possess inhibitory effect on Pseudomonas aeruginosa. A study by Kathleen (1999) shows that antimicrobial agents in aloevera can effectively kill the strains of Pseudomonas aeruginosa and a maximum zone for Staphylococcus aureus $(15 \mathrm{~mm})$, aloevera inhibits the growth of a wide variety of Gram negative and Gram positive bacteria.

Carrot had no effect on Pseudomonas aeruginosa, Salmonella typhi and Shigella flexineri while for E. coli it was $12 \mathrm{~mm}$ and Staphylococcus aureus $10 \mathrm{~mm}$.

Amla had zone of inhibition (13 mm) only for Salmonella typhi.

Honey had no effect on Salmonella typhi but had varying inhibitory effects on other four test organisms. Mundo et al., (2002) showed that honey had the ability to inhibit the growth of Escherichia coli. Studies have indicated that the growth of Staphylococcus aureus was inhibited by honey (Estrada et al., 2005). Antimicrobial properties of honey are well exhibited by the inhibition of Staphylococcus aureus in Muller Hinton agar (AI-Waili, 2004 and Moirin et al., 2003).

Pomegranate had good inhibitory effect on $E$. coli (10 mm), Salmonella typhi $(15 \mathrm{~mm})$ and Staphylococcus aureus $(12 \mathrm{~mm})$. Studies have shown that pomegranate can inhibit the growth of Staphylococcus aureus (Machado et al, 2003). 
Table 2: Results of standard well technique for the test bacteria

\begin{tabular}{|c|c|c|c|c|c|}
\hline \multirow{2}{*}{ ORGANISMS } & \multicolumn{5}{|c|}{ Diameter of zone of inhibition $(\mathrm{mm})$} \\
\hline & Aloevera & Carrot & Amla & Honey & Pomegranate \\
\hline Escherichia coli & 10 & 12 & - & 13 & 10 \\
\hline $\begin{array}{l}\text { Pseudomonas } \\
\text { aeruginosa }\end{array}$ & 11 & - & - & 15 & - \\
\hline $\begin{array}{l}\text { Salmonella } \\
\text { typhi }\end{array}$ & - & - & 13 & - & 15 \\
\hline $\begin{array}{l}\text { Shigella } \\
\text { flexineri }\end{array}$ & - & - & - & 10 & - \\
\hline $\begin{array}{l}\text { Staphylococcus } \\
\text { aureus }\end{array}$ & 15 & 10 & - & 15 & 12 \\
\hline
\end{tabular}

\section{Effect of antibiotics on test organisms}

\section{(a) Effect of antibiotics on Escherichia coli}

Escherichia coli is the most common cause of urinary tract infection. Gentamycin is the drug of first choice for diseases caused by Escherichia coli. Antibiogram results show that Amikacin gave a zone of inhibition of $14 \mathrm{~mm}$ and Gentamycin gave a zone of inhibition of $12 \mathrm{~mm}$. The zone of inhibition of other drugs Ampicillin, Bacitracin, Chloramphenicol and Streptomycin were not significant. This shows that Escherichia coli are becoming resistant to a broad-spectrum of drugs.

Table 3: Antibiotic inhibition of test bacteria

\begin{tabular}{|c|c|c|c|c|c|c|c|}
\hline S.No. & ORGANISMS & 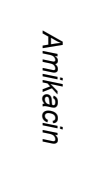 & $\frac{\substack{3 \\
\frac{3}{3}}}{\stackrel{5}{s}}$ & 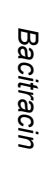 & 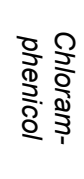 & 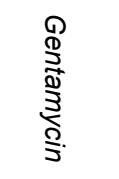 & 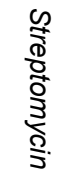 \\
\hline 1 & Escherichia coli & $14 \mathrm{~mm}$ & - & - & - & $12 \mathrm{~mm}$ & - \\
\hline 2 & Ps. aeruginosa & $12 \mathrm{~mm}$ & - & - & - & $13 \mathrm{~mm} 1$ & $12 \mathrm{~mm}$ \\
\hline 3 & Salmonella typhi & $12 \mathrm{~mm}$ & - & - & - & $10 \mathrm{~mm}$ & - \\
\hline 4 & Shigella flexineri & $12 \mathrm{~mm}$ & - & - & $8 \mathrm{~mm}$ & $10 \mathrm{~mm}$ & - \\
\hline 5 & $\begin{array}{l}\text { Staphylococcus } \\
\text { aureus }\end{array}$ & $15 \mathrm{~mm}$ & - & - & - & $12 \mathrm{~mm}$ & - \\
\hline
\end{tabular}

The experimental extracts showed a good inhibitory effect on Escherichia coli with honey showing a maximum inhibitory effect followed by carrot and thirdly aloevera and pomegranate showing equal inhibitory effect. Amla was not effective as it did not show any zone of inhibition. By antibiogram it was observed that the organism is resistant against a broad spectrum of drugs. Escherichia coli infection can be treated with honey, carrot, aloevera and pomegranate based on the results obtained.

\section{(b) Effect of antibiotics on Pseudomonas aeruginosa}

Pseudomonas aeruginosa is an opportunistic pathogen and is resistant to antibiotics makes it a significant cause of urinary tract infection. Drug of choice against this organism is Gentamycin. It was found from antibiogram studies that Pseudomonas aeruginosa was sensitive to Gentamycin with a zone of inhibition of $13 \mathrm{~mm}$ while Amikacin and Streptomycin showed an inhibitory range of $12 \mathrm{~mm}$.

The experimental extracts had a good effect on Pseudomonas aeruginosa. Honey was the most effective followed by aloevera. This is a unique breakthrough, since all strains of Pseudomonas aeruginosa are increasingly becoming drug resistant.

\section{(c) Effect of antibiotics on Salmonella typhi}

Salmonella typhi causes typhoid fever. Recently this organism has developed resistance against antibiotics. When tested only Amikacin and Gentamycin gave zone of inhibition of $12 \mathrm{~mm}$ and $10 \mathrm{~mm}$ respectively.

The experimental extracts showed inhibitory effect on Salmonella typhi with pomegranate showing the maximum inhibitory effect followed by amLa. These facts indicate that the experimental extracts of pomegranate and amLa can be used for the treatment of typhoid fever

\section{(d) Effect of antibiotics against Shigella flexineri}

Drug of first choice against Shigella flexineri is Chloramphenicol while alternative drug used is Ampicillin. Results of the antibiogram reveal that Shigella flexineri showed sensitivity to Amikacin, Gentamycin and Chloramphenicol with a zone of inhibition of $12 \mathrm{~mm}, 10$ $\mathrm{mm}$ and $8 \mathrm{~mm}$ respectively.

The experimental extract honey showed inhibitory effect on Shigella flexineri. This indicates that the aqueous extract of honey can be effectively used to combat infections caused by Shigella flexineri.

\section{(e) Effect of antibiotics against Staphylococcus aureus}

Staphylococcus aureus is responsible for the majority of the Streptococcal infections in humans particularly food poisoning through the production of toxic enzymes. When Staphylococcus aureus was tested against a range of drugs Amikacin showed an inhibition of $15 \mathrm{~mm}$ while Gentamycin showed an inhibition of $12 \mathrm{~mm}$.

Aloevera and honey was proved to be the most and equally effective in treating infections against Staphylococcus aureus followed by pomegranate and carrot. The experimental extracts conferring inhibitory effect on Staphylococcus aureus hold a promising position as a broad-spectrum therapeutic agent. The DNA and protein analysis was done in order to study the reason of inhibition of using pathogenic bacteria

\section{DNA Analysis}

DNA analysis was done to study the reason of inhibition of 
Table 4: DNA analysis of organism

\begin{tabular}{|c|c|c|c|}
\hline S.No. & Sample & Optical Density & $\begin{array}{c}\text { Amount of DNA } \\
\mathrm{mg} / \mathrm{mL}\end{array}$ \\
\hline 1 & Pseudomonas aeruginosa & 0.182 & 0.0110 \\
\hline 2 & Pseudomonas aeruginosa + Honey extract & 0.175 & 0.0108 \\
\hline 3 & Salmonella typhi & 0.197 & 0.0139 \\
\hline 4 & Salmonella typhi + Pomegranate extract & 0.180 & 0.0131 \\
\hline 5 & Staphylococcus aureus & 0.220 & 0.0176 \\
\hline 6 & Staphylococcus aureus + Aloevera extract & 0.198 & 0.0168 \\
\hline 7 & Staphylococcus aureus + Honey extract & 0.207 & 0.0164 \\
\hline 8 & Standard & 0.135 & \\
\hline
\end{tabular}

Table 5: Protein analysis of the organisms

\begin{tabular}{clcc}
\hline S.No. & Sample & Optical density & $\begin{array}{c}\text { Amount of Protein } \\
\text { mg/mL }\end{array}$ \\
\hline 1 & Pseudomonas aeruginosa & 0.382 & 0.319 \\
2 & Pseudomonas aeruginosa + Honey extract & 0.656 & 0.188 \\
3 & Salmonella typhi & 0.393 & 0.459 \\
4 & Salmonella typhi + Pomegranate extract & 0.369 & 0.178 \\
5 & Staphylococcus aureus & 0.515 & 0.323 \\
6 & Staphylococcus aureus + Aloevera extract & 0.501 & 0.146 \\
7 & Staphylococcus aureus + Honey extract & 0.510 & 0.169 \\
8 & Standard & 0.118 & \\
\hline
\end{tabular}

Table 6: Contents of the health drink and salad (one serving)

\begin{tabular}{c|c}
\hline Ingredients & Amount \\
\hline Pomegranate & $150 \mathrm{~mL} / \mathrm{gm}$ \\
Carrot & $100 \mathrm{~mL} / \mathrm{gm}$ \\
Amla & $25 \mathrm{~mL} / \mathrm{gm}$ \\
Honey & $15 \mathrm{~mL}$ \\
Aloevera juice & $10 \mathrm{~mL}$ \\
\hline
\end{tabular}

Table 7: Acceptability and palatability of the health drink and salad

\begin{tabular}{llc}
\hline Sensory attributes & Salad & Health drink \\
\hline Appearance & $4.6 \pm 0.89$ & $4.5 \pm 0.63$ \\
Colour & $4.5 \pm 0.74$ & $4.5 \pm 0.74$ \\
Consistency & $4.0 \pm 0.70$ & $4.3 \pm 0.90$ \\
Flavour & $4.0 \pm 0.77$ & $4.0 \pm 0.70$ \\
Taste & $4.3 \pm 0.89$ & $4.5 \pm 0.59$ \\
\hline
\end{tabular}

Table 8 Standard plate count for the food products

\begin{tabular}{ccc}
\hline Dilution & $\begin{array}{c}\text { Room } \\
\text { temperature }\end{array}$ & $\begin{array}{c}\text { Refrigerated } \\
\text { temperature }\end{array}$ \\
\hline $10^{-1}$ & No growth & No growth \\
$10^{-2}$ & No growth & No growth \\
$10^{-3}$ & No growth & No growth \\
\hline
\end{tabular}

the experimental extracts on the test organism. The results are given in Table 4. DNA estimation reveals that there is no significant difference between the test organism and those treated with the experimental extracts. It is evident from the results that DNA is affected at the transcriptional or translational level when the transcription of RNA to proteins occurs. They react with amino acid group resulting in cellular metabolism or alkylate amino, hydroxyl and carboxyl group leading to the formation of secondary protein structures.

\section{Protein Analysis}

Following the quantitative study of the experimental extracts on the test organism the protein estimation was done. The results are given in Table 5. Results of protein estimation indicate that there is a considerable decrease in the amount of protein when treated with the experimental extracts. The amount of protein in Pseudomonas aeruginosa is $0.319 \mathrm{mg} / \mathrm{mL}$. On treating with honey extract the organism contains only 0.188 $\mathrm{mg} / \mathrm{mL}$ of proteins. In Salmonella typhi the amount of protein is $0.459 \mathrm{mg} / \mathrm{mL}$ and on treatment with pomegranate extract the amount of protein is 0.178 $\mathrm{mg} / \mathrm{mL}$. The amount of protein in Staphylococcus aureus is 0.323 and is reduced to 0.146 and 0.169 on treatment with the experimental extracts of aloevera and honey respectively.

\section{Standardization and formulation of the health drink and salad}

Three trails were done before formulating the composition of the health drink and salad. Standard measuring cups and measuring spoons were used for the preparation of the health and salad. The experimental commodities chosen for the formulation were fresh and without any 
Table 9: Nutritive analysis of health drink

\begin{tabular}{lccccccc}
\hline Particulars & $\begin{array}{c}\text { Quantity } \\
(\mathrm{g} / \mathrm{mL})\end{array}$ & $\begin{array}{c}\text { Energy } \\
(\mathrm{kcal})\end{array}$ & Protein $(\mathrm{g})$ & $\begin{array}{c}\text { Carbohydrate } \\
(\mathrm{g})\end{array}$ & Fat $(\mathrm{g})$ & $\begin{array}{c}\text { Vitamin A } \\
(\mathrm{IU})\end{array}$ & Vitamin C (mg) \\
\hline Pomegranate & 150 & 97.5 & 3.07 & 22.5 & 0.12 & - & 24 \\
Amla & 25 & 14.5 & 0.12 & 3.4 & 0.02 & 3.75 & 150 \\
Carrot & 100 & 48.0 & 1.10 & 10.10 & 0.18 & 8045.58 & -3 \\
Honey & 15 & 31.9 & 0.04 & 12.7 & - & - & - \\
Aloevera & 10 & 1.7 & 0.50 & 0.06 & - & 0.12 \\
Total & 193.6 & 4.83 & 48.76 & 0.32 & 8049.33 & 178.92 \\
\hline
\end{tabular}

contamination and prepared in a clean and sterile environment Since aloevera, carrot, amla, honey and pomegranate have anti microbial effect, the consumption of the health drink and salad helps ingesting all nutrients in one stretch.

\section{Acceptability and palatability trial}

In product development, sensory evaluation plays a vital role for evaluation of products (Yan, 2001). When the quality of a food product is assessed by means of human sensory organs, the evaluation is said to be sensory or subjective. Sensory attributes are the most significant quality parameters for determining consumer acceptance (Lawless and Classen, 1993). Sensory evaluation is the only method for getting correct opinion of the target population and consumer acceptance of the product. Different rating scales are used for testing the product acceptance, out of these the hedonic scale is mostly used (Yeh et al., 1998).

In the present study a five point hedonic scale was used to evaluate the acceptability of the health drink and salad. The importance of appearance, colour, consistency, flavour and taste are significant when deciding to accept the food item or not (Areas et al., 2003). The health drink and salad was evaluated by a panel comprising of twelve members and the product was evaluated based on a five point hedonic scale score card as detailed earlier. The average scores obtained from the panel members for the acceptability and palatability of the health drink and salad are presented in Table 7.

From Table 7 it is evident that the sensory attributes like appearance, color, consistency, flavour and taste of salad and health drink was rated to be excellent with a mean score ranging between 4.0 to 5.0. The appearance of a product plays an important role in its acceptability. It forms the impression about the quality of the product. Colour of foods give pleasure and is index to the quality of food. Part of the acceptance of the food is how it looks. Although consistency may be considered as textural quality attribute, it can also be in food appearance. Flavour perception is the most complex of human behaviors, odour stimuli play a major role in perception of food flavour Taste plays an essential role in food selection and consequently overall nutrition.

\section{Shelf life of the health drink and salad}

The standard plate count was done at room and refrigerated temperatures to assess the shelf life of the health drink and salad. Table 8 shows the plate count at room and refrigerated temperatures for the food products. It can be seen from Table 8 that there was no growth of microorganisms seen in the plates for all the three dilutions. The test was done for the health drink and salad. Tests show that the health drink and salad was prepared under clean and sterile conditions using aloevera, carrot, amla, honey and pomegranate that were fresh and not contaminated. Table $\mathbf{9}$ shows the nutrients present in the health drink and salad which comprised of aloevera, carrot, amla, honey and pomegranate.

The nutritive value of the health drink and salad was calculated. The protein, carbohydrate, fat, Vitamin A and Vitamin C of aloevera, carrot, amla, honey and aloevera was analyzed in the laboratory. The health drink and salad had a low protein, low fat and moderate carbohydrate to content. Therapeutically this drink and salad can be used to treat obesity. High amounts of Vitamin A and Vitamin C was present in the health drink and salad due to the addition of carrot and amla. Vitamin A and Vitamin C and can be used in the prevention and treatment of cancer as it can fight against free radicals. The consumption of the health drink and salad could be encouraged as it not only had antimicrobial property but was also rich in vitamins and low in fat. The health drink and salad can be consumed as a mid-morning or evening snack or drink.

\section{REFERENCES}

Aggary, O. O., Olaleye, M. T., and Bello-Michael, C. O. (2005) .Comparative Anti-bacterial activities of 
aloevera gel and leaf. African Journal of Biotechnology, 197 (4): 11-14.

Al-Waili. N.S., Karger, P. A., and Centneron, D. T. (2004). Investigating effect of honey. Journal of Medicinal Food, 45(6) 100-107.

Areas, J. A. G., Charez, R.N. and Jauregui (2003). Acceptability of Snack Product. Int. Journal of Food Science and Technology 52 (5): 54-58.

Estrada, H., Lasade, K. and Gorhin, G. D. (2005). Evaluation of honey against microbes. Archives of Latinowa Nutr, Feb.42(30).

Gopalan, C., Sastri, V. R., and Balasubramanian, S. C. (2002). Nutritive value of Indian foods. ICMR National Institute of Nutrition, Hydebarad.

Kathleen, S. (1999) .Antimicrobial agents isolated from aloevera. Phamaceu Pat,March 31. Patent US Classification 424/744/43529435/32

Lawless, H.T. and Claassen, M. R. (1993). Application of central dogma in sensory evaluation. Food Tech. 47(6): 139-146.

Machado,T. B., Raxaner, F. and Flakner, L. P. (2003). In vitro activities of Brazilian Medicinal plants. International Journal of Antimicrobial Agents, July. 7(2): 45-48.

Moirin, P. L., Mated, B. F. and Wacgytin, A. (2003). Antimicrobial activities of honey. Journal of Applied Microbiology, July 2(4): 74-75

Mundo, M. A. and Worobo, R. W. (2002). Growth inhibition of pathogens and food spoilage microorganisms by raw honey. Food Microbiology 97(1): 1-8

Yan, N. J. N. (2002). Motives for food choice:A comparison of consumers from Japan, Taiwan, Malatsia and New Zealand. Food Quality and Preference. 98(3): 119-134

Yeh, L. L., Kim,K.O., Chrompreed, A. and Lundhal, D. S. (1998). Comparison of the use of the 9 point scale between Americans, Chinese, Koreans and Thai. Food Quality and Preference 9(6): 413-419 